\title{
Characterization and Three Dimensions of the Main Character in Looking for Alaska
}

\author{
I Ketut Suardi Utama \\ English Department - Faculty Of Arts - Udayana University \\ [tutsuardi@gmail.com]
}

\begin{abstract}
This study is entitled "Characterization and Three Dimensions of the Main Character in Looking For Alaska". This study is concerned with the method of the characterization based on the three dimensions of the main character and intrinsic elements in the novel. The main purpose of this study is to find out how the author presents the main character in terms of the physiological, psychological, and sociological dimensions. This study was based on library research and used documentation method in collecting data. Then the data obtained were analyzed descriptively using descriptive qualitative method. Some theories of characterization were used such as the theory of characterization proposed by Kenney (1966), the theory of character dimensions by Egri (1960). The data source of this study is a novel entitled Looking For Alaska by John Green (2011). The analysis started with the overview of the biography of John Green and that was followed by the synopsis of the novel, and the data was categorized based on the theories. Based on Kenney's theory, the main character is shaped through the mixing method of the characterization. In addition, based on Egri's theory, there are three character dimensions (physiological, psychological, and sociological) involved in the shaping and presentation of the main character.
\end{abstract}

Keywords: three dimension, method of characterization, main character.

\section{Abstrak}

Studi ini berjudul "Characterization and Three Dimensions of the Main Character in Looking For Alaska”. Penelitian ini berkaitan dengan metode karakterisasi berdasarkan tiga dimensi karakter utama dan elemen intrinsik dalam novel. Tujuan utama dari penelitian ini adalah untuk mengetahui bagaimana penulis menyajikan karakter utama dalam hal dimensi fisiologis, psikologis, dan sosiologis. Penelitian ini didasarkan pada penelitian kepustakaan dan metode dokumentasi yang digunakan dalam mengumpulkan data. Kemudian data yang diperoleh dianalisis secara deskriptif dengan menggunakan metode deskriptif kualitatif. Beberapa teori karakterisasi digunakan seperti teori karakterisasi yang diajukan oleh Kenney (1966), teori dimensi karakter oleh Egri (1960). Sumber data penelitian ini adalah sebuah novel berjudul Looking For Alaska oleh John Green (2011). Analisis dimulai dengan gambaran biografi John Green dan yang diikuti oleh sinopsis novel tersebut, dan data tersebut dikategorikan berdasarkan teori-teori tersebut. Berdasarkan teori Kenney, karakter utama dibentuk melalui metode pencampuran karakterisasi. Selain itu, berdasarkan teori Egri, ada tiga dimensi karakter (fisiologis, psikologis, dan sosiologis) yang terlibat dalam pembentukan dan penyajian karakter utama. 
Kata kunci: tiga dimensi, metode karakterisasi, karakter utama.

\section{Background of the study}

Literature is the form of human creativity consisting of idiom, feeling, idea, spirit and experience using the language as the medium and having positive impact on life. (Warren and Wellek, 1986:107).

Character is one important aspect because characters are built by the writer that has a function as a medium to introduce the reader to various characteristics of human beings, including negative characteristics as well. (Kenney, 1983; 45).

This study was focused on the method of characterization of the main character and three dimensions of the main character in the novel Looking for Alaska as can be seen in real life.

Novel as a literary work is chosen to be analyzed in this study because the novel has a lot of high value, massage and morality that the reader can get. Then curiosity will be felt by the reader about the author's depiction in expressing imagination that makes the reader drift into a story.

\section{Problems of the study}

There are two interesting problems based on the background above to be discussed:

1. What kind of characterization method used in presenting the main character in the novel Looking for Alaska?

2. How are three dimensions of the main character described in the novel Looking for Alaska?

\section{Aims of the study}

The aim of the study was to expand the reader's knowledge about literature, especially on the method of characterization and three dimensions (physiology, psychology and sociology) analysis. The aims of this study were to answer the problems mentioned above.

1. To identify the method of characterization used in presenting the main character in the novel Looking for Alaska.

2. To analyze how are the three dimensions of the main character described in the novel Looking for Alaska.

\section{Research Method}

Research method refers to the way adopted in conducting research, in order to solve the problems related to the study. It is an important step and procedure when we want to conduct scientific research. The method of this study consist of several parts, such as: data source, method and techniques of collecting data, and method, techniques of analyzing data and method of presenting the data.

\subsection{Data Source}

Data source is the source where analyzed data are taken. The data were taken from the novel Looking for Alaska in the form of conversations of the main character. The novel was written by John Green. The novel was released on March 2005 by Dutton Juvenile and this edition published in 2011.

\subsection{Method and technique of Collecting Data}

The technique that was used in collecting data is note-taking technique. This method was done by these following techniques: First, the researcher needed to compile the data, by which putting all the data together in one place in such a way that they were more easily analyzed and interpreted. Second, the researcher focused on reading the novel carefully to 
identify the personality, habit, and behavior of the main character, comprehensive reading was needed. In other words, the analysis was focused on the method of characterization and three dimensions of the main character in the story. The next step was reading the theory books and browsing the internet, in order to obtain more relevant information.

\subsection{Method and Technique of Analyzing Data}

The data in this study were analyzed using the qualitative method. The data were presented descriptively according to the theories adopted for easier understanding on the analysis. The potential, important, and promising data which had been collected were identified by highlighting sentences. The next step was diminishing the data in order to get the valid one. The theory of literature proposed by Kenney in his book How to Analyzed Fiction was used to classify the main character and characterization. Meanwhile, theory of the three dimensions analysis proposed by Lajos Egri (in Sukada; 1987:135) Beberapa Aspek Tentang Sastra was used to find out the three dimensions.

\subsection{Method and Technique of Presenting Data}

Descriptive qualitative method was used to present data analysis. The results of data analysis were presented based on two problems.

The results of data analysis of the first problem were shown through conversation and the explanation based on the theory of characterization by Kenney (1966:34) that consists of dramatic method and character on other character method).

\section{Analysis}

In describing Miles as main character in Looking for Alaska novel, two methods of characterization were used, they are:

\subsection{Method of Characterization \\ 5.1.1 The Dramatic Method}

This story tells that Miles is bored with his minor life in Florida and then he decided to leave his parents in Florida to go to Culver Creek Boarding School in Alabama. Miles believed that there had to be more to the world than this. Miles is obsessed with the last words to seek a Great Perhaps from famous poet Francois Rabelais.

\section{Data 1}

The week before I left my family and Florida and the rest of my minor life to go to boarding school in Alabama.............................(Gre en, 2011:09).

The sentences above show that Miles was bored with his life in Florida and he decided to attend the Culver Creek to seek a great perhaps, because he wanted to change his life for the better one. It is supported by the sentence The week before I left my family and Florida and the rest of my minor life to go to boarding school in Alabama. Therefore, it can be concluded the author presented that Miles was bored with his minor life through the dramatic method, because the author allows the character to reveal themselves through their own words.

\subsubsection{Character on another Character}

This story tells that they were under the bridge; they called it the Smoking Hole because this place is safe for them to smoke. Then they discussed who ratted out Marya and Paul. At that time Alaska had no sympathy for them. Alaska and Miles were flirting each other and Alaska always mentioned her boyfriend every time she complimented Miles.

\section{Data 2}


"You're adorable," she said, and I felt the intensity of her eyes on me and look away

nervously.".............................. .."Yeah, Pudge is adorable"...............(Green,2011:56)

Based on the sentences above, Miles friends said that he was an adorable person; it occurred when they were smoking on rickety wooden bridge. It is supported by the sentence You're adorable,"Yeah, Pudge is adorable. Therefore, it can be concluded that the author presented Miles as an adorable person through the character on other character because one of the character in a story talks about another character.

\subsection{Three Dimensions}

\subsubsection{Physiological dimension of the} Main Character

\section{a. Appearance}

The author presents that Mile had a thin body; it occurred when Miles took a bath in the small bathroom. He stated, My skinniness always surprised me: my thin arms didn't seem to get much bigger as they move from wrist to shoulder. From the quote had shown above.

\section{Data 3}

The small bathroom contained a huge......My skinniness always surprised me: my thin arms didn't seem to get much bigger as they move from wrist to shoulder...... (Green, 2011:15). Pudge, I've seen your chicken legs entirely too often. (Green, 2011:23).

Miles is a skinny man, it said, when he took a shower and surprising him small bathroom contained a huge, full-length mirror behind the door, he could not escape the reflection of his naked self as he leaned in to turn on the shower faucet, and he enjoyed the softness of the soap suds and the cold water that flowed from the faucet through his back bone, where he was looking in the mirror endlessly and he said his skinny always surprised him. It also occurred when his friend said "Pudge, I've seen your chicken legs entirely too often". As the quotes show, it can be concluded that his weight is not proportional or it can be said he is a skinny man.

\subsubsection{Psychological dimension of the Main Character}

a. Personality

\section{Data 4}

We

made out way to the TV room......Chip said hello to a few people, but didn't introduce me...........(Green, 2011,19)

Miles Halter is an extrovert person, because he likes hanging with other people around him. It is explained when Miles and The Colonel made out way to the TV room over the summer to find The Colonel Stuff. The television room undulated with youngsters trying to find and haul away their stuff and then the Colonel greeted people in there and he said hello to a few people. The Colonel at that time did not introduce Miles to them, but actually Miles really wanted to know them so that he had more friends in the boarding school. It was stated in Miles' comments in the quotation above that he was an extrovert person.

\subsubsection{Sociological Dimension of the Main Character}

\section{a. Amusements}

\section{Data 5}

......Pudge memorises people's last words......(Green,

2011:23).................. (Green, 2011:26)......"A lot of times, people die how they live. And so last words tell me a lot about who people were, and why they became the sort of people 
biographies get written about. Does that make sense?" (Green, 2011:156)

Miles is a junior in high school who likes memorizing famous writer last words. The last words have more meaning for him than what many people think last words mean and he believed the last words that the famous writer can changed his life in the future. He took the famous writer's last words (I go to seek a great perhaps) for changing his life to be better one and he has enough selfawareness to know that he won't find his Great Perhaps at home in Florida (last word by Francois Rabelais). Therefore, he decided to go to Culver Creek to seek a Great Perhaps, which has something more for him.

\section{Conclusion}

From the analysis in the previous chapters, there were several points that could be concluded as the conclusions on this study. They are:

The method of characterization used by the author is the mixing method, which includes the dramatic method in which the character reveals himself through their words and actions and character on the character method in which the personality of the main character was presented by the other character in the story.

From the three dimensions under concern it can be concluded that Miles Halter is an adorable man who has extrovert personality because he likes hanging with other people. From the analysis it can be concluded that the author applied mixing method, which means applying more than one method and this analysis also explains how the main character is being described in terms of three dimensions.

\section{Bibliography}

Abrams, M.H.1970. A Glossary of Literary Terms. New York: Holt, Rinehart and Winston.Inc. Accessed on $16^{\text {th }}$ of June 2016. Available from: http://www.ohio.edu/people/hartl eyg/ref../abrams_mh.pdf

Agustini, Kadek, 2009. The Analysis of Main Character in the Color Purple by Alice Walker. An undergraduated paper. Denpasar: Faculty of letters and culture. Udayana University.

Budiman, Novita. 2009. The Analysis of the Main Character in the Mark Twain's Novel 'The Adventure of Huckleberry Find. An undergraduated paper. Denpasar: Faculty of letters and culture. Udayana University.

Di Yani, Robert. 2001. Literature, Reading Fiction, Poetry and Drama. New York :McGrowHill, Inc

Egri, Lajos. 196. The Art of Dramatic Writing. New York: Simon \& Schuster, Inc. Accessed on $16^{\text {th }}$ of June 2016. Available from: http://www.itworkss.com/downlo ad/Books/Lajos/Egri/The/Art/Of/ Dramatic/writting.pdf

Hornby, A.S.2005. Oxford Advanced Learner's Dictionary - $17^{\text {th }}$ Edition.England: Oxford University Press.

Kenney, William. 1966. How to Analyze Fiction. Monarch Press. United States of America.

Kusuma, Putu Anindia A. 2008. An Analysis of Main Characters in Dickens's The Adventure of 
Oliver Twist. An undergraduated paper. Denpasar: Faculty of letters and culture. Udayana University.

Nurgiantoro, Burhan. 1995. Theory Pengkajian Fiksi. Gadjah Mada. University Press.

Paramjeet, Kaur and other.2013. " $A$ Study Of Personality Types Of The Teacher Trainer Of Jammu”. A Journal of Radix International Educational and Research Consortium, Vol.2, Issue 8: page 1-14. Accessed on $16^{\text {th }}$ of June 2016. Available from: http://www.rierc.org/social/paper 264.pdf

Sukada, Made Drs. 1987. Beberapa Aspek Tentang Sastra. Penerbit Kayumas \& Yayasan Imu dan Seni Lesiba.

Stanford, Judith. 2006. Responding to Literature: Stories, Poems, Plays, and Essays.

McGraw-Hill Humanities/Social Sciences/Language.

Wellek, Rene; Warren Austin. 1962. Theory of Literature. London: Lowe \& Brytone. Ltd.

http://www.psychoshare.com/file142/psikologi-kepribadian/teori-teoridalam-psikologi-kepribadian.html 